\title{
The Changing Face of Rural Enterprises
}

Since the 1970s these enterprises have been accommodating and adjusting to the ever-moving institutional environment

Wei Zou

\section{OpenEdition}

\section{Journals}

Édition électronique

URL : http://journals.openedition.org/chinaperspectives/773

DOI : 10.4000/chinaperspectives.773

ISSN : 1996-4617

Éditeur

Centre d'étude français sur la Chine contemporaine

\section{Édition imprimée}

Date de publication : 1 décembre 2003

ISSN : 2070-3449

Référence électronique

Wei Zou, «The Changing Face of Rural Enterprises », China Perspectives [En ligne], 50 | novemberdecember 2003, mis en ligne le 19 avril 2007, consulté le 28 octobre 2019. URL : http:// journals.openedition.org/chinaperspectives/773 ; DOI : 10.4000/chinaperspectives.773

Ce document a été généré automatiquement le 28 octobre 2019

(c) All rights reserved 


\section{The Changing Face of Rural Enterprises}

Since the 1970s these enterprises have been accommodating and adjusting to the ever-moving institutional environment

\section{Wei Zou}

1 The aim of this paper ${ }^{1}$ is to provide an overview of the emergence and development of China's xiangzhen qiye, the township and village enterprises (TVEs) ${ }^{2}$, from an institutional viewpoint. The questions that interest us include: How is it that TVEs emerged under seemingly adverse political and economic conditions? How have they been able to achieve such an exceptional performance over the past two decades? What role did central and local governments play in their development? What role have TVEs played in China's economic reforms as a whole? Is the development of TVEs a special case in China alone or is it a paradigm that can be generalised to other less developed countries? We emphasise the point that the emergence of the TVEs is not a forced institutional change designed and guided by the central government, but an induced institutional innovation that began within the society. Instead of seeing TVEs as a onceand-for-all institutional invention, we treat the institutional innovation embodied in TVEs as a function of the institutional environment per se. The endogeneity of institutional innovation not only contributes greatly to TVE development but is also an alternative approach to rural industrialisation.

During the last two decades, China has pursued rural industrialisation at an unprecedented speed through the development of the TVEs. Although other economies, such as Taiwan's, took similar roads to rural industrialisation, TVEs in China have no equal elsewhere in their unprecedented growth rate and magnitude. Official statistics indicate that from 1978 to 1994, the average annual growth rate of rural industrial output was about $27 \%$, almost three times the growth rate of national GDP. Rural industry surpassed agriculture in size in 1987 and now comprises half of the total Chinese economy. From 1986 to 1998, the average asset scale of TVEs increased tenfold and the average scale annual growth rate is about $25 \%$ (see figures 1 to 5 ). 
3 The magnitude and exceptional performance of the TVEs in China have drawn the attention of the international academic community. The new growth theory emphasises the positive externality created by accumulated knowledge, human capital and social capital in stimulating sustainable growth ${ }^{3}$. Culture theory addresses the role of co-operative culture among Chinese villages in enhancing TVE development ${ }^{4}$. Others, so fascinated by the perversion of public firms owned by local governments, that they regarded the public ownership of TVEs as static, optimal institutional choices by peasants ${ }^{5}$. Another theory explains the success of TVEs from a standpoint of comparative advantage ${ }^{6}$. While these studies may serve as explanations for the success enjoyed by TVEs in 1980s, they do not analyse the specific institutional environment and its change behind the TVE performance, nor do they offer a comprehensive framework for predicting the likely development of TVEs.

4 In contrast with the experience of Eastern Europe where privatisation also took place and the privatised enterprises operated without direct interference of government, TVEs are neither state-owned nor private enterprises, and are innately correlated with local government. Many people think TVEs have benefited from their vaguely-defined property rights, from the two-track economic system under transition and from the paternalist care of local officials, yet this experience is too specific to be generalised as a model for rural industrialisation. The slowdown of TVE growth since 1990 clouds their prospects. While the general significance of TVE development is doubted, the dynamism of the nature of the TVEs is rarely mentioned. This paper will trace the path of endogenous institutional innovation within them.

We first present a brief description of the institutional environment in rural China up to the 1970s to explain the emergence of the TVEs in the late 1970s and early 1980s. We then focus on the 1980s when TVEs prospered, and analyse the specific ownership in these enterprises. The problem at the heart of this debate is the role of local governments, the nature of collective ownership in TVEs and the related significance of this to TVE performance. We continue with their reorganisation, restructuring and privatisation since the 1990s, and end in summary with the dynamic change in the institutional structure in TVEs over the last three decades.

The emergence of TVEs as an induced institutional innovation

6 An institution is a set of behavioural rules which pertain to social, political and economic behaviour, and are used to govern a variety of social interactions ${ }^{7}$. Institutions can be separated into two categories: institutional environment and institutional arrangement. The former is the set of fundamental political, social and legal ground rules that govern the ways in which people can co-operate and/or compete with each other ${ }^{8}$. Most people mixed these two categories and treated the institutional change as an exogenous variable. Others focus on some kind of institutional arrangement, e.g. ownership, while supposing the institutional environment is always given'. Yet in a less developed economy, both institutional environment and institutional arrangement are far from optimal and need reform. Our first step will be to briefly summarise the institutional environment in pre-reform rural China to explain why TVEs emerged at that time and what they meant to rural China.

7 China has a history of a hugely diversified and more or less isolated rural economy. Before 1949, the output of handicraft workshops and other household sideline production in rural China was about 1.16 billion yuan in 1957 prices $^{10}$, which is not an accurate figure if taking into account the lengthy civil war. All the workshops then 
were privately owned and operated. The natural development of rural capitalism was cut off and pre-reform rural China witnessed two nationwide industrialisation campaigns.

8 The first of these was the rural co-operative movement in the 1950s. Because of the nationwide collective dream and the uncertainty of political winds, few dared to form handicraft co-operatives even though they were asked to. In 1957, the value of sideline production only accounted for roughly $4.3 \%$ of the total rural output. Rural industry was on the verge of disappearing. Obviously dissatisfied with the poverty and backwardness in rural China, central government moved further to implement communist industrialisation. In the Great Leap Forward period of 1958-59, consistent with the heavy industry development strategy, large-scale commune and brigade enterprises (shedui qiye) were established, many of which were engaged in the production of steel with rudimentary technology. These enterprises employed 18 million people by the end of 1958 , but the results were catastrophic and triggered acute shortages and nationwide famine. In the subsequent years, the output value of commune and brigade enterprises plunged to 410 million yuan (1957 prices) in 1963, i.e., only $35 \%$ of the value in 1949. During the following six years, the development of rural industry was in stagnation. On the one hand, although private enterprises were compatible with the backward condition in rural China and transaction cost-saving, the political costs were too high to sustain them. On the other hand, it was impossible for communist industrialisation to succeed. Although the political costs were in reality fairly low, the wide-spread poverty and immobility of resources, could hardly support industrialisation on such a huge scale.

Then came the second industrialisation in the early 1970s, when central government emphasised agricultural mechanisms and there appeared a tendency for decentralisation in economic planning and an advocate for "self-reliance". Many rural areas tried again to set up commune and brigade enterprises manufacturing agricultural machinery, repairing tools, providing hydroelectric power or supplying construction materials. Despite their limitations in technology, scale and management, the output of commune and brigade enterprises grew at an average rate of $25.7 \%$ during 1972-76 ${ }^{11}$. Basically, these enterprises were politically safe due to their communist ownership, and economically acceptable due to their small size, localdependency and primary technology. 


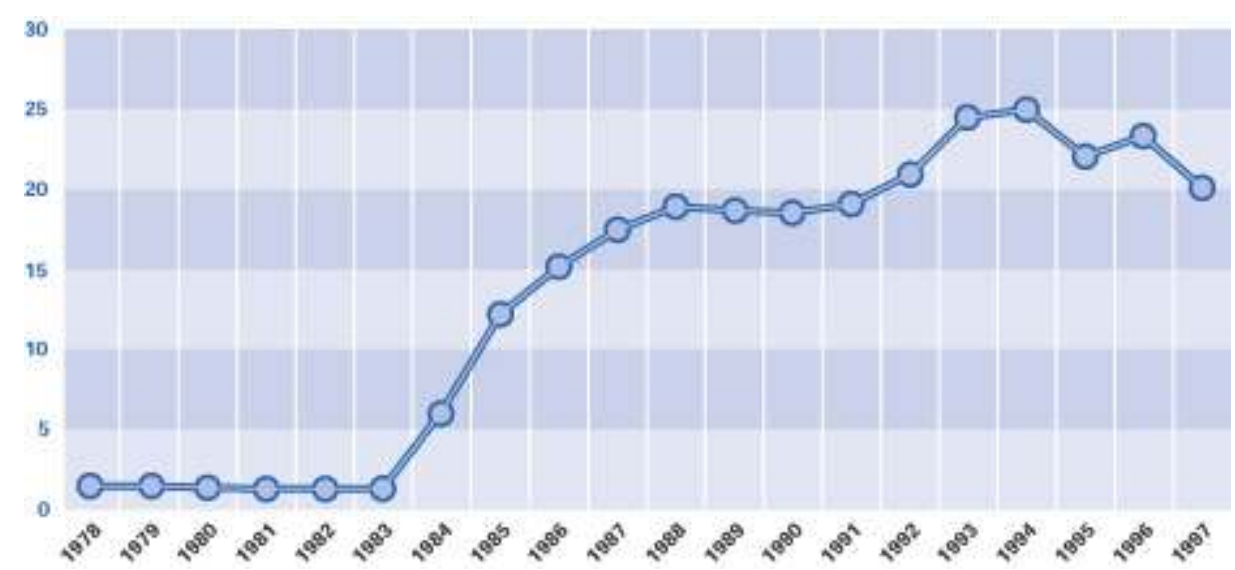

Sources: China Statistical Yearbook, 1997, 1998. The Yearbook of Chinese Township and Village Enterprises, 1995, 1996 1997, 1998. China Economic Yearbook, 1997, 1998.

The spurt in the growth of TVEs in the late 1970s and early 1980s was not a natural evolution of commune and brigade enterprises. Even in 1978, the output value of commune and brigade enterprises only accounted for $21.2 \%$ of total rural output, and their employment only $9.5 \%$ of total rural labour. These enterprises were targeted at agricultural modernisation rather than at absorbing rural labour, they paid more attention to political requirement than to economic rationale. They were consequences of political movement implemented by the state, but the emergence of TVEs was not designed or guided by the state, even not known to the latter. The peasants took advantage of cheap land and labour, semi-formal or informal fund-pooling, the authority of the existing rural hierarchy or kinship, of local market and low transaction costs, of central government ignorance, and eroding control over income disparity since the adoption of the household responsibility system, and gradually shifted their resources into rural industry.

11 TVEs emerged spontaneously first in relatively resource-abundant coastal areas, especially the Yangze and Pearl River deltas, then expanded to relatively isolated central areas. Because of the differences in economic or institutional factors, such as the traditional resource base, proximity to markets and to urban industry, pre-1949 industrial and commercial traditions, delivery requirements for grain and other crops under the agricultural planning system, and pre-reform rural industrialisation, there was a remarkable degree of diversity among TVEs. What interests us most is the plurality of ownership structures in TVEs.

The nature of TVEs and their dynamism

The intimate relationship witnessed between local governments and TVEs has long been singled out as an important characteristic of TVEs and has instigated great academic interest and controversy. The negative school regards the TVEs as a partially successful makeshift, half-way house to real private ownership ${ }^{12}$. Others take a positive viewpoint, yet differ in their arguments. Some regard the involvement of local governments as a central government decision to co-ordinate the decentralised market economy with a relatively centralised political system ${ }^{13}$. Some see the collective firms in rural China as a manifestation of cultural common sense ${ }^{14}$. Some link the local government ownership with imperfect market, imperfect information, and the 
gradualist features of China's reform ${ }^{15}$. Still others regard TVEs as an informal joint venture between the state and the private sector, and as a result, they benefit from both the collective system and privatisation ${ }^{16}$.

The negative school pays too much attention to the strain or even contradiction between local governments and TVEs. Actually the marriage between these two were not always involuntary. The positive school is right in its more or less institutional perspective, yet both the institutional arrangements and the institutional environment are taken as static or exogenous. We will analyse the nature of TVEs and its dynamism from emergence up to now to shed light on how the ownership in TVEs has been changing according to the institutional environment.

1978-1984: collective ownership dominates

14 During this phase, collective ownership dominated across the country, even in 1984, $67.46 \%$ of TVE employment and $85.63 \%$ of TVE output came from collectives. The features of collective ownership in TVEs can be summarised as:

- 1. The production factors (land, labour, capital and materials, etc.) were owned by the community. Namely each person in the community had the same amount of property and no-one had complete ownership.

- 2. There was no mobility of production factors across communities. Capital accumulation and fund-raising was restricted in the town or village and conducted by the local governments.

- 3. There was no possibility for members of the community to transfer their rights to TVE property. If they left the community, they automatically lost their part of the property.

- 4. The rewards for members of the community were wages or public services provided by local governments. TVEs profits were controlled by local governments, rather than by any single entity.

- 5. The leaders of local governments had a big say in production, management and distribution of TVEs, yet they still treated collective TVEs as public property.

\section{Labor force employed in TVEs}

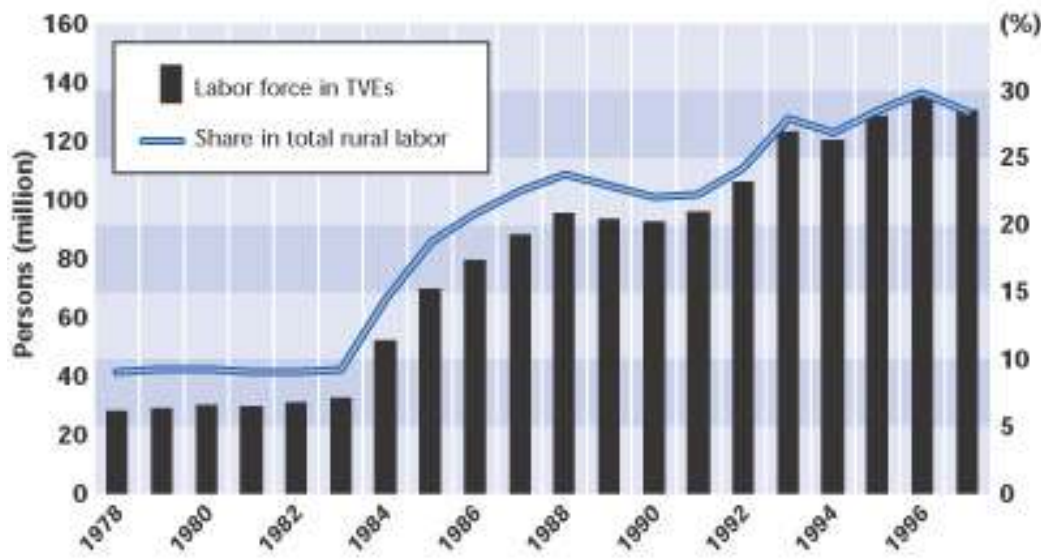

Sources: China Statistical Yearbook, 1997, 1998. The Yearbook of Chinese Township and Village Enterprises, 1995, 1996 1997, 1998. China Economic Yearbook, 1997, 1998.

15 Compared with standard property rights, the property rights structure of TVEs is incomplete. Ownership is not exclusive (figures 1 and 2), or transferable (figure 3). Nor 
is there a specific entity responsible (figures 4 and 5). As publicly-owned entities, what collective TVEs are to a small rural community is what state-owned enterprises are to the Chinese. It is easy to predict that TVEs may perform just as poorly state-owned enterprises due to the vaguely-defined property rights. Yet TVE performance was much better than expected. It seems to challenge the property rights theory, which is based on the context of a developed economy, yet the ownership arrangement in TVEs reflects only the institutional environment from which it emerged.

16 The planning system dominated the allocation of production factors, which was strongly favourable to collective enterprises. It was a long time before the prices of most products were finally liberalised. The important materials-steel, coal, wood, etc.-were strictly controlled and rationed because of severe shortages. In 1981, 53\% of the production of coal was rationed; $52 \%$ of steel production was rationed. In 1983, the percentages were still as high as $51 \%$ and $58 \%$ respectively ${ }^{17}$. In rural areas, local governments were privileged enough to be able to allocate the materials that served as a precondition for the establishment of TVEs. Also, most of the TVEs emerged as resources-based industries, needing to accumulate agricultural products, such as grain, cotton, oil, etc., as inputs. But most agricultural products circulated within the planning system. Usually the private enterprises had to pay twice the prices paid by collective enterprises for inputs from state units or supply-and-marketing co-ops. In some cases, it may be almost impossible to obtain rationed inputs such as cement or timber without resorting to corruption. Instead of repeatedly bribing the local government officials, the peasant households often found that it paid to put their enterprises under collective control.

17 Collective TVEs had more access to land, one of the most precious resources in rural China with a high labour-to-land ratio. Land shortages worsened, and competition for land became fiercer with the establishment of small and medium-sized towns and the upsurge of TVEs. The local governments tended to assign land to collective TVEs because they were considered as collective assets. In some land-short societies there was also a tendency to hoard land. Because land was allocated by the state, specialised local bureaus and collective TVEs considered it their own property. They frequently acquired more land than they could use and even let it lie idle for possible future use, aggravating the land shortage and making it even more difficult for private enterprises to get land.

18 Additionally, collective TVEs enjoy easy and low interest rate loans. Lack of capital and underdevelopment of rural financing system were severe problems in rural China. Since Rural Credit Co-operatives (RCC) have long been directed by the highly concentrated plan system, the relationship between these co-operatives and local government was strong, while that between the RCCs and the farmers was weak. The volume of loan funds was too limited, and the loan-to-deposit ratio was low. Interest rates were not flexible and ill-suited to the competitive terrain. RCCs seemed to fall between formal and informal financial systems. Formal because it was under the control of Agricultural Bank of China, the bank specialising in supporting rural development and implementing rural policies, and informal because it used to be manipulated by local government to wield significant power upon TVEs without proper economic accounting. Obviously, the RCCs have extended more loans to collective TVEs than to private enterprises because of government directives, not because the 
collective TVEs are intrinsically more efficient or because local banks recognised that the local governments were better assessors of risk.

Secondly, there was a tradition for local officials to interfere in economic activities, with an expectation of taking advantage of their political priority to make themselves better off not only economically but also politically. Actually economic performance has always been one of the most important criteria for official promotion at each level. Government officials, through the frequent, political movements against right-wing tendencies, realised that it was better for them to keep a left-wing front on economic activities. Moreover, learning from the experience of central government control over the state-owned enterprises, local officials tended to take collective ownership of TVEs for granted. This created an environment in which TVEs could hardly develop without being owned, managed or closely entwined with local governments.

There were 1.5 million commune and brigade enterprises in 1978, with employment of 28 million and gross income of 43,000 million yuan ${ }^{18}$. These firms were directly controlled by local governments and were renamed TVEs in 1984 . The pre-reform rural bureaucracy remained largely intact despite organisational reform that had led to abolition of the commune system, and kept powerful control over economic activities including those of TVEs. The newly established township government, which constituted the lowest level of the formal state structure, reflected extensive organisational changes in line with the shift to greater reliance on market coordination. However, there remained considerable overlapping of ties between the township governments and the new corporations that were supposed to manage enterprises. Frequently the same cadres who were most influential in the township governments also held prominent positions in the new township corporations. Moreover, many cadres who had served in the former commune administration remained prominent in the new township governments. They controlled the RCCs, mobilised the resources, decided the allocation of land, and managed economic activities in a dictatorial way. So on the township or town level, almost all the large TVEs were transferred from former commune and brigade enterprises.

21 At the village level, the situation seemed to be different. The institutional reforms, especially the prevalence of the household responsibility system, had a greater impact. Village cadres had little direct control over the management of economic activities since collective enterprises were leased to private parties, equipment sold out, and land assigned to individual households. But village cadres still influenced the economy by negotiating contracts and leases, and acting as middlemen and brokers in local economic transactions. Nonetheless, the power of village cadres had shrunk considerably, leaving room for private enterprises (usually less than five employees in size) to emerge at village level.

Thirdly, the organisational environment was favourable for direct local government control over TVEs. The legal system in China was quite incomplete. Instead of implementing a single law with regard to all enterprises, there were different laws for different enterprises. Yet there was no specific law for TVEs until as late as 1997. So the hierarchical administration for TVEs was inconsistent both vertically and horizontally. TVEs used to be seen as a supplement to agriculture, the vertical administrative structure supervising them was rather loose. Unlike other industrial sectors in China that are defined by product type, TVEs included any factory, firm, enterprise, hotel and shop located in the rural areas. There was a great diversity in TVE production, almost 
covering all the sectors. Thus TVEs were subject to much vertical administration. The Township Enterprise Administrative, established in 1979 under the Ministry of Agriculture, was supposed to be the top bureaucratic structure guiding rural industries, but other ministries and commissions had their own offices for rural industry. Because rural industrial production crossed so many product lines and therefore challenged the products of so many ministries, most ministries had to co-ordinate with rural industries in some manner. The same situation existed at the provincial level. As a result, these overlapping bureaucracies actually provided such a loose supervision that direct control often lied with the local governments.

For example, county supply and marketing co-operatives, which until the mid-1980s had a monopoly on the purchase and sale of most agricultural inputs and production, controlled a large number of rural enterprises. In Wujiang County of Suzhou Municipality, the supply and marketing co-operatives owned 42 factories and employed more than 8,000 workers $^{19}$. In Zouping County, Shandong province, there were 26 collective enterprises under county control. Among them, 11 were owned by the supply and marketing co-ops ${ }^{20}$. The most important reason for government intervention was that TVEs had become the local governments' main source of revenue. With the introduction of the household responsibility system, each level of local governments contacted with its immediate superior to turn over a fixed amount of funds and keep the remaining surplus. As a result, "local governments use every method possible, including many that straddle the boundaries of legality, to promote rural industry, at the same time milking it to supplement their government budget".

Fourthly, The political environment was favourable for experimentalism in rural areas. Due to long-lasting poverty and sharp inequality between rural and urban areas, central government began to pay more attention to countryside grievances, complaints and strong desire for de-collectivisation. As far as peasants were concerned, their pursuit for private interest was a cause rather than a consequence of reform. The initiative to do away with collective farming, surreptitiously at first and increasingly openly later, essentially confronting the regime with a fait accompli. They also knew that their pursuit of prosperity could not be fulfilled if in contradiction with communist political requirements. After their experience of the household responsibility system, the peasants realised that local governments could selectively implement policies from central government and the connivance and cover-ups by sympathetic local cadres could help TVEs survive before they got official authorisation.

As for central government, there was a rapid change in the political climate, particularly the tolerance of experimentation symbolised by the slogan, "truth through facts" (shishi qiushi). From 1978-84, although without sanction from the central government, the number of rural enterprises increased fourfold, the amount of labour force doubled, gross output value increased fourfold. The significant performance surprised the central government so much that it finally stepped in to express its support. In 1984, TVEs were formally named xiangzhen qiye. And the peasants were highly encouraged to find their own ways to prosperity, among which TVEs were suggested successful.

Therefore, in the first phrase, TVEs appeared in advance of the extant institutional framework and were more or less underground. They had to be firmly rooted in the pre-reform institutional environment and take advantage of the leeway of inconsistency of the administration system. Their survival depended on two different, 
but connected capabilities. One was management capability to make production decisions. The other, synthesised as "procurement capability", was the ability to coordinate in a non-market allocation system, to obtain preferential policy treatment, and to solve disputes with other production units at low cost through economic and non-economic methods. During this phase, management capability seemed not so significant, because there was little competition from state-owned enterprises and among TVEs due to the immobility of factors and the shortage of consumer goods markets. But procurement capability may have been of great importance due to the lack of markets, especially factor markets. TVE managers had to get production factors, loans, licences, etc., through administrative bureaucrats other than through markets. Most productions and transactions were personalised and access to scarce inputs was a matter of privilege. The contracts were costly to write and enforce because many business rules were either vaguely defined or hard to enforce. Taking advantage of the original administrative resources, the direct control of local governments helped to reduce their management and transaction costs.

1984-89: The Diversity of Ownership

In this phrase, the dominance of collective ownership weakened, a variety of ownership appeared with a sharp increase in private enterprises. In 1984, $72.7 \%$ of rural TVE enterprises were peasant-run joint co-operative (gufen hezuo danwei) and private businesses (siying qiye), and produced 16\% of TVE output value ${ }^{21}$. In 1985, non-collective rural enterprises increased to $87.1 \%$. Their contribution to TVE output value increased to $27.1 \%$ (see figures 6 and 7). The diversity of ownership was also an endogenous consequence of the then changed institutional environment.

A slowdown of agrarian development emerged due to the worsening of agricultural returns. In 1984, the grain output dropped for the first time since 1978 and stagnated until 1989, which symbolised the decreasing returns to the one-shot household responsibility system reform. Agricultural investment from all sources lagged, leading to a decline in such indicators as area covered by irrigation. Rural per capita income, which had more than doubled between 1978 and 1984, largely stagnated in real terms during the remainders of the 1980s. An important reason for this was that in 1985, the state in effect lowered procurement prices for grain to reduce the costs of buying above-quota grain and the burdens of subsiding urban consumers, while keeping high industrial input prices.

\section{Gross output of TVEs}

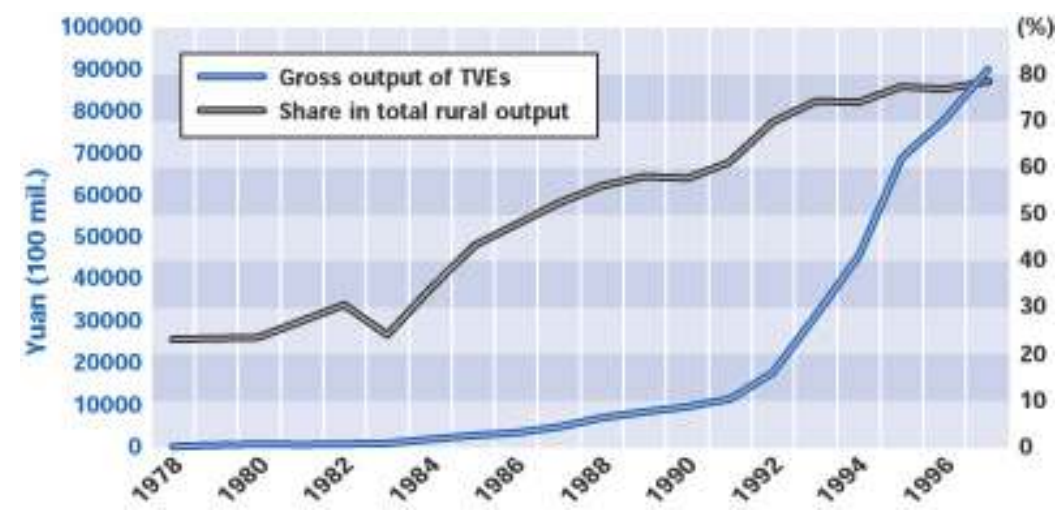

Sources: China Statistical Yearbook, 1997, 1998. The Yearbook of Chinese Township and Village Enterprises, 1995, 1996 1997, 1998. China Economic Yearbook, 1997, 1998. 


\section{Industrial output of TVEs}

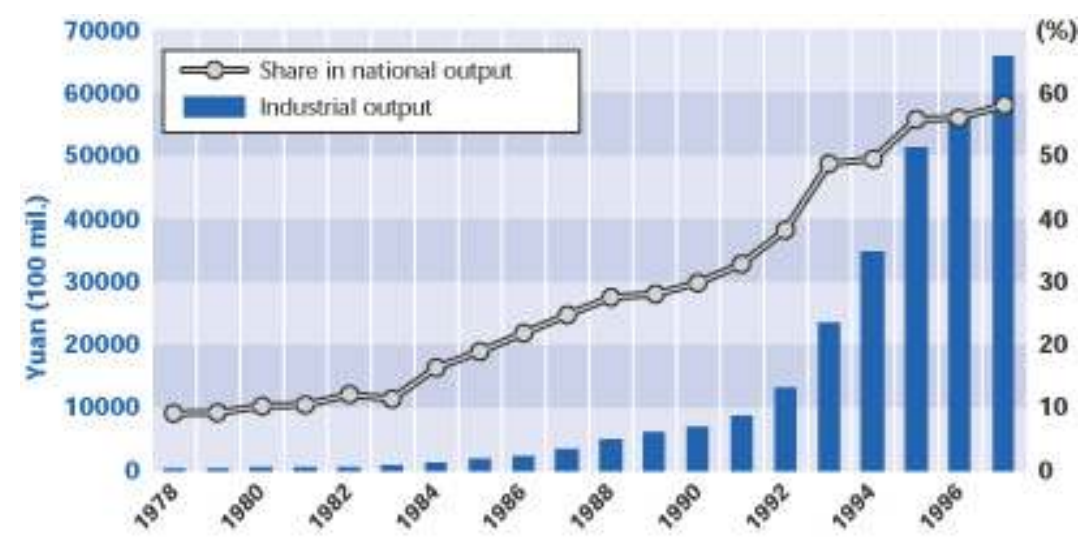

Sources: China Statistical Yearbook, 1997, 1998. The Yearbook of Chinese Township and Village Enterprises, 1995, 1996 1997, 1998. China Economic Yearbook, 1997, 1998.

This situation led to two-fold results. Agriculture could no longer support TVEs by production factors and capital accumulation, it even became a drain on local resources. More and more peasants were pushed away from agrarian activity because of the enlarging disparities between those whose earnings came largely from non-agricultural sources and those standard farmers. Rural income in the coastal provinces, where TVEs were concentrated, grew much more rapidly than in the central and western provinces. Due to the rural territorial inequality, farmers complained that it did not pay to farm. Local governments accordingly tried to divert procurement funds to more profitable purposes (e.g., hounding diesel fuel and selling at market prices), which resulted in a large-scale issuance of IOUs (bai tiao) and further disadvantaging farms.

The political climate changed in favour of the development of non-collective enterprises. The economic policies from the central government can be summarised as the following popular slogans then. First, "controlling better by controlling less" (fenquan rangli). The decentralised fiscal and personnel system was designed to increase responsibilities and incentive, it also encouraged local cadres to be hyper-responsive to their immediate superiors and hyper-enthusiastic in collecting fiscal revenues. Second, "White or black, a cat is good as long as it can catch rats" (bulun baimao heimao, zhuadao laoshu jiu shi haomao). Deng's words gave an indirect permission for diversity in ownership structures, and they were interpreted by lower-level cadres as "collective or private, an enterprise is good as long as it can contribute revenues". Third, "let a few people get rich first" (rang yibufen ren xian fu qilai). Rural China has a deep belief in Confucianism and a long tradition for egalitarian distribution of income, but people were unwilling to put with the resulting equally widespread poverty any longer, the government also had to compromise. Fourth, "wait and see" (guanwang). There was a tendency for central government to reaffirm private enterprises. Although there were rules restricting private enterprises to a rather small size, the government did not immediately stop or punish violations of the rules. In 1988, a constitutional amendment was drafted giving private enterprises owners legal status for the first time since the 1950s. 


\section{Contribution of TVEs to rural income per capita}

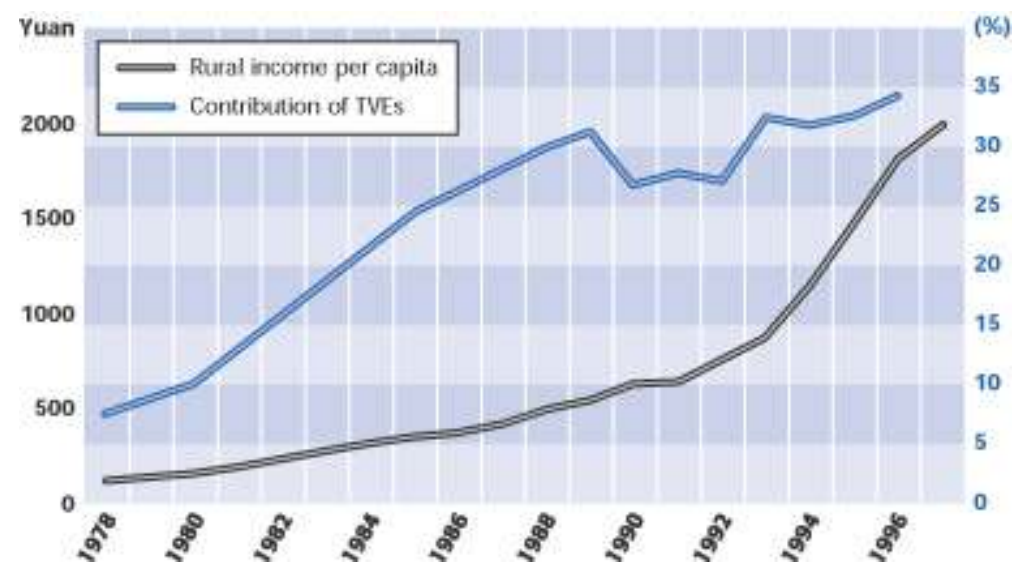

Sources: China Statistical Yearbook, 1997, 1998. The Yearbook of Chinese Township and Village Enterprises, 1995, 1996 1997, 1998. China Economic Yearbook, 1997, 1998.

Industrial profits and taxes were the main source of local prosperity. Rural industry yielded funds essential for the building of infrastructure that could sustain further industrialisation and attract outside, including foreign, investment. Mindful of the link between outstanding performance and attractive rewards, local cadres were strongly motivated to seek "impressive achievements" (zheng ji). By then, economic development has been made the central task of the state and the Party. Governments at every level wanted to showcase their achievements by finishing some "visible projects" during their tenure of office. To finance these undertakings, they had no choice but to order their subordinates to pursue higher growth rates and extract more from the local population. As the pursuit of economic growth snowballed, local governments loosened the regulation on all kinds of rural enterprises. The unprecedented development of private rural enterprises is a result. In 1984 there were 4.2 million private rural enterprises, accounting for $69.28 \%$ in the total number of TVEs, while they accounted for $23.54 \%$ of TVE employment and $14.37 \%$ of TVE output. But one year later, the private rural enterprises surged to 10.37 million ( $84.87 \%$ of total TVEs), accounting for $38 \%$ of total rural labour, and the percentage of their output in TVE output value increased by more than 10 points to about (see figures 6 and 7).

During this nascent period, ownership in private rural enterprises was incomplete. At the beginning, private enterprises were legitimate mainly through their small size and marginality. There were five main sources for private owners and managers: lowerlevel local government cadres or former cadres; supply and marketing personnel of collective TVEs; employees with technical skills; former workers of state-owned enterprises; and farmers. The success of private enterprises depended more on such "capable persons" than on funds, land, labour, and the other factors of production. These capable persons, although without much formal education in management, had an innate sensitivity to the market and had, more or less, access to scarce resources under the planning system. Generally the owners of household factories were responsible for all their profits or losses, they had a stronger incentive for accumulation and development. Yet the operating environment of private enterprises was still unpredictable and risky. In those areas where the traditional collective economy was strong, private enterprises were discriminated against or even confiscated to leave room for collective TVEs. Taking advantage of the political 
environment, local governments exploited and crowded out private enterprises for non-economic reasons. In 1985, when the burgeoning private and lower village enterprises drew labour and business away from county- and township-owned firms in Wuxi County, Jiangsu province, the local government imposed restrictions upon these firms. Relatives of the skilled workers who left collective enterprises to work for private ones were permanently barred from jobs in TVEs. By these methods, the county drove out the competition, allowing private enterprises to survive only in commerce, transport and services ${ }^{22}$.

\section{Labor force in private TVEs}

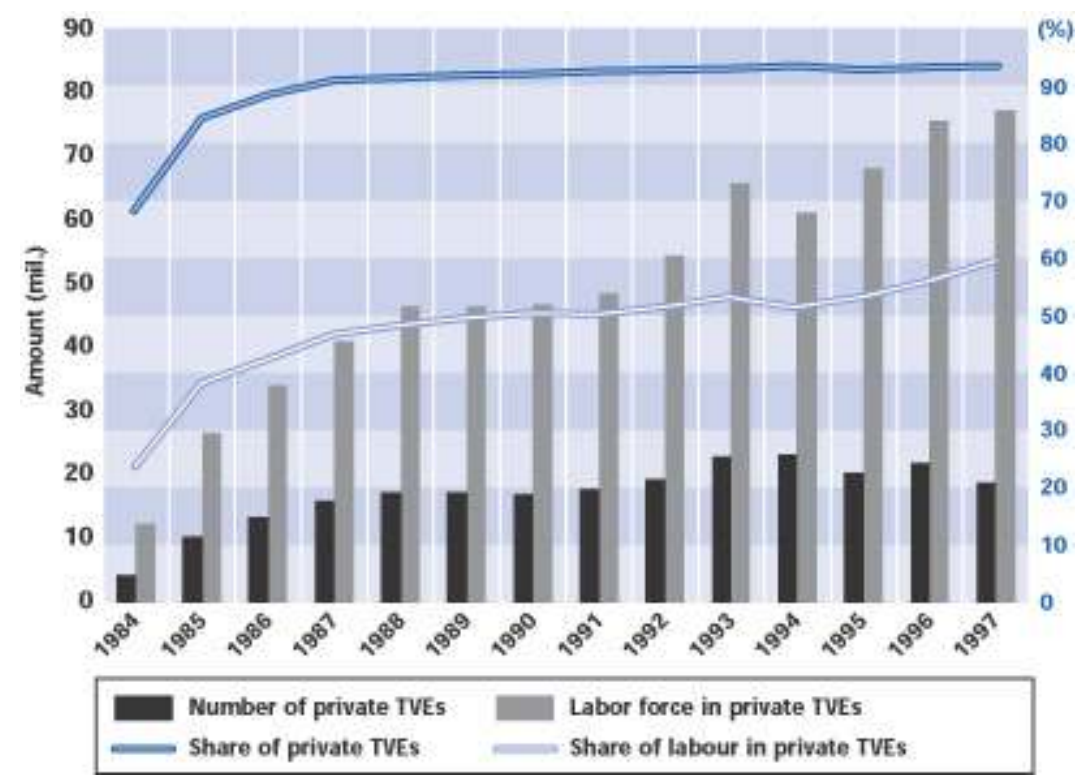

Sources: China Statistical Yearbook, 1997. The Yearbook of Chinese Township and Village Enterprises, 1995, 1998. China Economic Yearbook, 1998.

Insecure property rights and imperfect markets are common features of transitional and developing economies. But China has long held an anti-capitalism, anti-private property ideology that the peasant households always feared to be economically correct, but politically incorrect. The political hazard was not just perceived, it was actual fact even in 1980s. For example, during the "anti-spiritual pollution campaign" of 1983, during the "anti-bourgeois liberalisation campaign" in 1987, and after the Tian'anmen Square Incident of 1989, private enterprises usually came under attack for speculation, profiteering, tax evasion, sale of fake products, pornography and other social ills.

Much of the fieldwork (Nee and Young, 1990; Odgaard, 199023) shows that local governments adopted different attitudes towards different private enterprises, which to a great degree determined how far and how fast the private enterprises can move towards capitalism. The private enterprises chose their ownership structure accordingly. Generally there were three kinds of private enterprises: joint family enterprises (lianhu qiye), individual enterprises (geti qiye), and large private enterprises (siying qiye). Joint family enterprises, usually received support from most cadres because they were believed to be able to spread their wealth around in a village and are easier to control due to their dependence on public support for inputs and supplies. Individual enterprises also had fairly broad cadre support because they were usually 
based on technical skills and could benefit the local community with revenue redistribution. As long as these individuals kept good relations with cadres, they could survive without political impediments. Most of the controversy lay with the large private enterprises. They competed with collective enterprises to a much higher degree, they aggravated the inequality in income distribution, and even generated social conflict in the villages.

Besides legal means of controlling their development, local cadres resorted to illegal means to convert successful large private enterprises into collective enterprises, or to confiscating their business licences. In Renshou County, Sichuan province, a very successful entrepreneur producing bamboo furniture for export was ordered to convert his large enterprise into a collectively owned enterprise. He objected and threatened to take the case to court. After some time, a compromise was reached: the entrepreneur could keep his factory if he conducted a training programme to pass his special skills to technicians in collective enterprises. Another entrepreneur faced a similar threat of expropriation. The village committee intended to take over his profitable cotton mill. $\mathrm{He}$ was less fortunate and eventually his business licence was officially revoked under the guise of shortage of electric power, while a village-operated cotton mill was built less than 50 miles away, using the same source of energy ${ }^{24}$. The local government aimed to sabotage competition from private enterprise once they learnt of their profitability.

However, peasant households were used to circumventing policy barriers and making compromises to protect their interests (as the bamboo producer did). Most private enterprises, small as they were, survived. To make their property rights not only economically viable, but also politically secure, they would spontaneously curb the scale of development. The relatively larger private enterprises, mostly took the name of "co-operatives" or "collectives" and blurred the property rights of their enterprises as a response to the policy instability, the lack of rule of law, and the ensuing disorder and inefficiency in the regulatory environment. So there was a medley of ownership arrangements in rural private enterprises, yet this feature helped the group of private enterprises to meddle through the muddy water of bureaucracy and transition.

After 1989: the restructuring and privatisation of TVEs

In the 1990s, a lot of embarrassing problems are reported in the TVEs. In addition to being criticised as capturing the market share of the large state-owned enterprises, wasting resources, creating pollution in rural areas, providing poor-quality products, distorting the market by rent-seeking activities, TVEs also suffered from a slowdown in growth rate and deterioration in main management indicators. In 1999, the average rate of debt in TVEs was about 65\%. In Wujin, Jiangsu, the debt rate of TVEs was $75.36 \%$ on average, while in some was as high as $95 \%{ }^{25}$. Early in 1993, losses in TVEs were at $3.84 \%$, and about three million had to shut down. This increased to $7.58 \%$ in 1994 , and $15 \%$ in 1997. In some provinces with relatively developed TVEs, losses also accumulated, in Jiangsu and Zhejiang, these were at $10 \%$ and $13 \%$ respectively.

39 Many people think the difficulties experienced by the TVEs resulted from the Asian financial crisis and the subsequent drop in exports. Actually as early as 1993, evidence for the slowdown was obvious. The crisis made things worse, especially for those coastal areas that depended more on export and foreign investment. The sluggish domestic market resulted in a huge involuntary inventory in TVEs, which even worsened the lack of working capital. The inefficiency of the state-owned enterprises and increasing urban unemployment and more lay-offs made it more difficult for rural 
labour to migrate to urban areas. The decrease of procurement prices of agricultural products and continuous decrease of rural income left little room for TVEs to raise funds and expand rural markets. The historical linkage with the local community restricted factor mobility, restrained the diffusion of information and technology, and resulted in a similar structure of production and products across communities. In many areas, technological innovation had been stagnant for years because of "tight budgets, disconnected distribution channels, broken information systems, and dispersed personnel" 26 . Most of the problems were concealed when there was a wide shortage in the domestic market and competition between different communities and different enterprises was not so fierce. As the domestic market changes from a seller's to a buyer's market, and as the ration system gives way to the market system for resource allocation, the former advantage from community linkages becomes a disadvantage or even a burden. The extraordinary growth of TVEs based on the transitive institutional environment is reduced to the normal growth rate painfully and with disturbance.

Roughly speaking, there are two groups of TVEs. The "Sunan Model" is based upon the former commune and brigade enterprises, mainly owned by the community and operated by politically powerful cadres in an authoritarian way, and in which the income distribution is relatively equal. Most of these TVEs are located in areas with a deep-rooted planning economy, e.g. south of Jiangsu (Sunan), from which comes the name. The "Wenzhou Model" emerged in 1980s, was mainly small-scale, owned by rural "capable persons" or elites, operated in a very flexible way to meet market demand for miscellaneous items. Most of these TVEs are located in the south-east coastal areas, typically Wenzhou in Zhejiang province.

41 Early in the 1990s, the collective TVEs only accounted for about 7\% of TVEs, yet for 44\% of employment and $69 \%$ of assets. They were usually called the "aircraft carriers" in rural industry. Small as they were in employment and assets, private enterprises have accounted for the lion's share in terms of the number of TVEs. But TVEs from different groups have experienced the same "symptoms".

- 1. The labour absorptive capacity in TVEs dropped sharply. From 1978-84, elasticity of employment to output was 0.57 , but it dropped to 0.26 in 1993, then to 0.15 in 1994. In 1997, TVEs only absorbed four million rural labourers, compared with an average of 7.17 million in $1985-90$.

- 2. Part of TVEs endured the "state-owned enterprises disease", such as loose and inactive management, unclear responsibility, too much social duty or family burden, too much interference from government.

- 3. The competitiveness declined due to too frequent shift in markets, "guerilla-style" management and increasing labour costs.

- 4. Disputes and lawsuits around property increased, and the average life expectancy of TVEs shortened.

The reasons for the difficulties lay in the vaguely-defined property rights. In the 1990s, the conflict between local governments and the TVEs become a serious problem in rural China. The focus of the conflict was the heavy burden imposed on the TVEs. With the fiscal decentralisation, local governments were given "the right to do", but not enough "right of financing". They extended their hands to the pockets of the peasants, and in particular to the more lucrative TVEs. This is usually referred to as "killing the hen to get the eggs" or "drying the lake to catch fish". Many TVEs were suffocated by the pressure of market and local governments and remained on the edge of 
bankruptcy. Awareness of these crises pushed the "Sunan Model", and the profit-pulled "Wenzhou Model" to restructure their ownership and reform their governance. The restructuring of ownership was referred to by many local officials as "changing from higher-level ownership to lower-level ownership", i.e. from collective to private ownership. When calculating "the rate of restructuring", they summed up those that have shifted from collective to private hands. In Wujin County, Jiangsu province, the rate of restructuring was $73 \%$ in 1995 and $84.2 \%$ in 1996. Among 3,287 TVEs, 58 merged into enterprise groups, 68 became shareholder co-operatives, 1,408 were leased, 55 auctioned, 221 sold, and 638 mortgaged. Similar data could be found elsewhere, which showed a movement of privatisation. Both models changed so spontaneously and at a similar time (started in 1993 in Zhejiang and spread in 1995 to Jiangsu) that there seemed to be a convergence between them.

By restructuring, collective TVEs are supposed to become shareholder companies or shareholder co-operatives, to be sold (or half-sold-half-rented) or to be auctioned. In 1993-94, most local governments preferred the "shareholder company" or "cooperative", yet few know how to set up and manage this type of company. There are a great number of "pseudo-shareholder" companies in the following features:

- 1. Most restructured TVEs have few shareholders, whose investment but not shares is counted;

- 2. Most shareholders are from the same town, village or even the same family;

- 3. In many companies, shareholders hold equal shares, in others the bosses dominate all small shareholders;

- 4. Most companies never issue equities to people outside their communities;

- 5. Most shareholders keep the shares only when they stay in the companies, they can withdraw their investment but cannot transfer their shares to others;

- 6. Few shareholders care about their rights of participation or supervision, and never pay attention to the difference between "one vote one share" and "one person one vote";

- 7. Many former managers naturally enjoy a new title and the biggest part of shares without any change in operation or management. Although the shareholder TVEs are assumed to be independent legal persons, they still bear the core of rural tradition in fund-raising, employment, management and distribution. The efforts of directly restructuring TVEs into shareholder enterprises turned out to be not as successful as expected. 


\section{Gross output of private TVEs 7.Gross output of private TVEs}

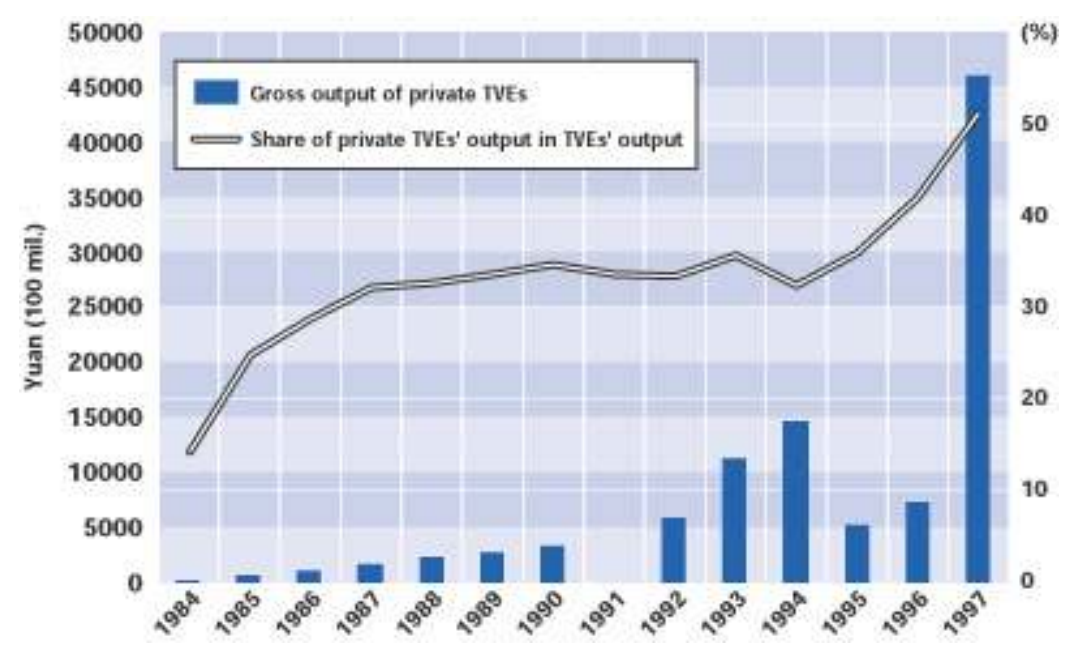

Sources: China Statistical Yearbook, 1997. The Yearbook of Chinese Township and Village Enterprises, 1995, 1998. China Economic Yearbook, 1998.

Since 1995, privatisation has been the hot topic in TVEs. Actually the advantage of rural government in allocating resources has been challenged, eroded and shaken by the restructuring of TVEs. The macroeconomic situation also made further privatisation possible. Private, joint-venture and co-operative enterprises mushroomed in China and state-owned enterprises have been reformed since 1984. More informal and private credit institutions were set up with the commercialisation of the financial system. Collective TVEs lost their tax advantage after the taxation reform in 1994. Collective TVEs have become so large and involved in diverse activities that they are very costly for local governments to supervise. Actually, the withdrawal of local governments from TVEs as owners is not forced by central government, nor by the request of peasants, but is based on the cost-benefit analysis. The benefits from collective TVEs have reduced to now being hardly able to cover the cost and trouble of running them. It is actually more profitable to sell them. Although in official documents, only those smallsized, vaguely profitable or inefficient collective TVEs can be sold, in practice, those bigger and more efficient TVEs are the first choice for sale. Local governments regard TVEs as their daughters, once beginning to "marry" them, they choose to marry out the prettiest ones. As for the less pretty or ugly ones, they try to lower the price or even transfer them as gifts to existing managers. Meanwhile, most "red-capped" private TVEs are taking off the cap and becoming real private ones.

With the privatisation movement, more and more private TVEs try to set up shareholder companies with clearly-defined property rights, yet there is still a long way to go. Generally owners have a very strong kinship with the local community, and besides their personal pecuniary goals, they have many other non-pecuniary goals including providing employment and a secure future for the family members; and improving social and official status. Since the property rights and the full financial rewards of entrepreneurs are not $100 \%$ secure, the incentives of private owners are largely distorted. They use every opportunity to profit through legal or illegal means and to take advantage of loopholes in the government's regulatory system. They are unwilling to undertake projects that require long-term investment, and prefer to spend their earnings on building luxurious houses and purchasing other living facilities. But they do not depend on community governments for financial or managerial help any 
more. Equity financing plays a more important role in corporate finance. According to official statistics, from 1994-98, the equity capital in TVEs increased $17.85 \%$ annually, and the percentage of equity in the whole capital increased from $36.02 \%$ to $39.73 \%$. While the debt ratio dropped from $65.73 \%$ in 1993 to $60.27 \%$ in 1998. More TVEs are going public and transfer of equity is allowed. More TVEs separate ownership and management, formalising such activities as decision-making, accounting and inside auditing. A new generation of TVEs is preparing to compete with the state-owned enterprises and foreign companies marching into China following China's entry into the WTO.

The past two decades in rural China evidenced a huge change initiated by the unprecedented industrialisation. In a less developed economy, rural industrialisation is always the toughest and most important problem within the process of economic development and transition. TVEs, although they develop with strong characteristics based on the specific features of the Chinese economy, provide an alternative approach to rural industrialisation in an economy with an incomplete market system, loose legal system, inefficient bureaucratic hierarchy, and more or less adverse environment for the cultivation of entrepreneurship in isolated rural areas.

TVEs emerge from historically backward agriculture and rudimentary rural industry. The economic landscape and environment in pre-reform China is typical in most less developed economies, especially those Asian economies with a high labour-land ratio and a low level of rural mechanisation. TVEs, instead of developing as a one-shot institutional arrangement, are adjusting to the different institutional environment one step at a time. Thus they pursue a self-correcting, self-enforcing path in their development, which greatly reduces the transaction costs during transition. This experience is of significance for those less developed economies with a deep-rooted traditional economy and little acknowledgement for the modern economic system.

As the institutional environment moves in a direction favourable to a freer market economy, TVEs also restructure their institutional arrangement from an improvised, transitory ownership arrangement to a more formalised well-defined property rights arrangement. There may be some distortion or even chaos during the adjustment, the former experience of gradual adjustment to different institutional environment helps to smooth the rearrangement. This leaves rural China as well as other less developed rural economies a legacy to steel any political or economic winds.

The change occurring in rural China with the development of the TVEs is not a simple passage from one order to another, but rearrangements in the patterns of how multiple orders are interwoven. The Chinese economy is in transition, yet the rural China is undergoing a transformation. Sometimes, the rural transformation goes in advance of the transition (just as happened in the late 1970s and early 1980s), and the transformation takes a disguised structure as a compromise. Sometimes the transformation goes hand in hand with the transition and results in a flourishing achievement (as happened throughout the 1980s). Sometimes the transformation lags behind the transition and suffers harsh experience (as happened in the 1990s). Yet transformation continues to occur through adaptations, rearrangements, permutations and reconfigurations of the existing institutional environment and organisational forms. With all the past performance and future prospects, China's experience of TVE development serves as an alternative approach to rural industrialisation. 


\section{NOTES}

1. The author is greatly indebted to Dwight Perkins, Jeffrey Sachs of Harvard University; Gustav Ranis, T. N. Srinivasan, T. P. Schultz of Yale University; Thomas Rawski of University of Pittsburgh; Gary Jefferson of Brandeis University, and referees, for very helpful comments and suggestions. I gratefully acknowledge the financial support form the National Science Foundation of China (\#70203008), the Ministry of Education (\#02JAZJD790022), and Harvard-Yenching Institute. The views expressed are my own and do not necessarily represent those of any organisation mentioned. 2. In Chinese statistics, rural enterprises include all the enterprises at or below township level, regardless of their ownership structures. These enterprises include not only those operating in industries, but also those operating in construction, transportation, commerce and food services. Although the number of private enterprises is increasing, official statistics still, and since 1984, summarise them as "non-agricultural township and village enterprises". We adopt the definition and refer to them as TVEs.

3. World Bank, The East Asian Miracle, New York, Oxford University Press, 1993.

4. Weitzman, Martin and Chenggang Xu, "Chinese Township Village Enterprises as Vaguely Defined Cooperatives”, Journal of Comparative Economics, No. 18, 1994, pp. 121-45.

5. Li David, “Ambiguous Property Rights in Transition Economics”, Journal of Comparative Economics, No. 23, 1994, pp. 1-19.

6. Lin Justin $Y$, "Rural Reforms and Agricultural Growth in China", American Economic Review, Vol. 82, No. 1, 1992, pp. 34-51. Lin Justin Y., Fang Cai, and Zhou Li, The China Miracle: Development Strategy and Economic Reform, Hong Kong, The Chinese University Press, 1996.

7. North Douglass C., Institutions, Institutional Change And Economic Performance, Cambridge University Press, 1990.

8. Davis Lance E. and North Douglass C., "Institutional Change and American Economic Growth: A first Step Towards a Theory of Institutional Innovation", Journal of Economic History, Vol. 30, No. 1, March 1970, pp. 131-49.

9. Tian Guoqiang, "Property Rights and the Nature of Chinese Collective Enterprises", Journal of Comparative Economics, Vol. 28, No. 2, 2000, pp. 247-68.

10. Byrd William and Qingsong Lin, China's Rural Industry: Structure, Development, and Reform. Oxford University Press, 1990.

11. Byrd and Lin, op. cit.

12. Sachs Jeffrey and Wing Thye Woo, "Understanding China's Economic Performance", NBER Working Paper 5935, 1997.

13. Chang Chun and Yijiang Wang, "The Nature of the Township Enterprises", Journal of Comparative Economics, No. 19, 1994, pp. 434-52. Che Jiahua and Qian Yingyi, "Insecure Property Rights and Government Ownership of Firms", Quarterly Journal of Economics, 1998.

14. Weitzman and $\mathrm{Xu}$, op. cit. Putterman Louis, "On the Past and Future of China's Township and Village-owned Enterprises”, World Development, Vol. 25, No. 10, 1997, pp. 1693-655. 
15. Li David, “Ambiguous Property Rights in Transition Economics”, op. cit. Naughton, Barry, "Chinese Institutional Innovation and Privatization from Below", American Economic Review, Vol. 84, No. 2, 1994, pp. 266-70. Naughton, Barry, Growing out of the Plan: Chinese Economic Reform, 1978-1993, Cambridge University Press, 1995.

16. Nee Victor "Changing Mechanisms of Stratification in China", American Journal of Sociology, Vol. 101, No. 4, 1996, pp. 908-949. Oi Jean, “The Role of Local State in China's Transitional Economy”, The China Quarterly, No. 144, 1995, pp. 1132-1149.

17. China Statistical Yearbook, 1991.

18. Griffin Keith ed, Institutional Reform and Economic Development in the Chinese Countryside, New York, M.E.Sharpe, Inc., 1984.

19. Zweig David, Freeing China's Farmers: Rural Restructuring in the Reform Era, New York, London, M.E. Sharpe, 1997, 365 pp.

20. Walder Andrew G., Zouping in Transition. The process of reform in rural North China, Cambridge, Massachussetts, London, Harvard University Press, 1998, 277 pp.

21. China Agricultural Yearbook, 1986.

22. Luo Xiaopeng, "Ownership and Status Stratification”, in William Byrd and Qingsong Lin, eds., China's Rural Industry: Structure, Development, and Reform, New York, Oxford University Press, 1990.

23. Nee Victor and Young Frank W., "Peasant Entrepreneurs in China's Sector Economy: An Institutional Analysis", Working Papers for Transitions from State Socialism, Cornell University, Ithaca, N.Y. 14853, 1990. Odgaard Ole, "Collective control of income distribution: a case study of private enterprises in Sichuan province", in Remaking Peasant China, ed. by J. Delman, Aarhus University Press, 1990.

24. Odgaard, "Collective Control of Income Distribution: A Case Study of Private Enterprises in Sichuan Province", op. cit.

25. Zhongguo Xiangzheng Qiye, 1999.7.

26. The Greenbook of China Agriculture Development, China Finance Publishing Press, 1993. 